\title{
DETERMINAN KEBIJAKAN DIVIDEN PADA PERUSAHAAN MANUFAKTUR DI JAKARTA ISLAMIC INDEX]
}

\author{
Novy Adityasari \\ Mahasiswa Program Studi S1 Ekonomi Islam-Fakultas Ekonomi dan Bisnis-Universitas Airlangga \\ Email: novy.adityasari-13@feb.unair.ac.id
}

Dina Fitrisia Septiarini

Departemen Ekonomi Syariah-Fakultas Ekonomi dan Bisnis-Universitas Airlangga

Email: dina.fitrisia@feb.unair.ac.id

\begin{abstract}
ABTRACT:
Dividend policy is a decision to determine the percentage of net profit of the company distributed to the shareholders as cash dividend which known as dividend payout ratio and the rest is percentage of retained earnings of the company. This study aims to determine factors that affect dividend policy on Manufacturing Company in Jakarta Islamic Index such as firm size, profitability, solvency and systematic risk. This study used panel data regression with Econometric Views (EViews) 8.0 as statistical analysis software. The samples are five manufacturing companies listed in Jakarta Islamic Index, during 2009 to 2015, the hypothesis test result showed that factors are firm size, profitability, solvency has significant result affecting dividend policy of manufacturing companies in Jakarta Islamic Index.
\end{abstract}

Keywords: Dividend Policy, Firm Size, Profitability, Solvency, Systematic Risk

\section{PENDAHULUAN}

\section{Latar Belakang}

Indonesia merupakan negara dengan industri manufaktur yang kuat. Ditengah pelambatan ekonomi nasional, industri manufaktur masih terus bertumbuh. Berdasarkan International Yearbook of Industrial Statistic 2016 yang diterbitkan oleh United Nations Industrial Development Organization (UNIDO), Indonesia berhasil masuk 10 besar negara industri manufaktur terbesar di dunia. Bahkan, Indonesia mampu melampaui negara industri seperti Inggris, Rusia, dan Kanada. Industri manufaktur adalah salah satu sektor yang memberikan kontribusi yang cukup besar terhadap pertumbuhan ekonomi dan terbukanya lapangan kerja yang mampu menunjang perekonomian Indonesia. (www.ekbis.sindonews.com)
Syariat Islam sangat menganjurkan umatnya untuk senantiasa menggunakan harta atau vang yang dimiliki untuk usaha yang produktif dan melarang memperjual-belikan uang (transaksi berbunga), oleh karena itu upaya untuk memutar modal dengan cara berinvestasi sehingga mendatangkan return merupakan aktivitas yang sangat dianjurkan dalam Islam karena dengan berinvestasi harta akan menjadi produktif dan mendatangkan kemaslahatan bagi individu maupun pertumbuhan ekonomi secara luas (Muhamad, 2014:435). Anjuran untuk bekerja dan berinvestasi telah disampaikan dalam Al- Qur'an, yaitu pada QS. At-Taubah: 105, sebagai berikut

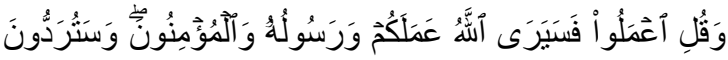

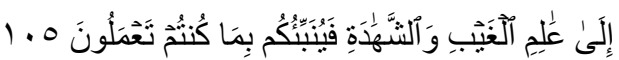


Adityasari, et al/ Jurnal Ekonomi Syariah Teori dan Terapan Vol. 5 No. 5 Mei 2018: 420-432; DeterMINAN KEBIJAKAN DIVIDEN PADA PERUSAHAAN MANUFAKTUR DI JAKARTA ISLAMIC INDEX

wa-quli 'malū fa-sa-yarā llāhu 'amalakum warasūluhu wa-l-mu 'minūna wa-sa-turaddūna 'ilā 'ālimi l-ghaybi wa-sh-shahādati fa-yunabbi' ukum bi-mā kuntum ta`malun.

Artinya : Dan katakanlah, "Bekerjalah kalian maka Allah dan Rasul-Nya serta orang-orang mukmin akan melihat pekerjaan kalian itu, dan kalian akan dikembalikan kepada (Allah) yang mengetahui akan yang ghaib dan yang nyata, lalu diberitakan - Nya kepada kalian apa yang telah kalian kerjakan" (QS. AtTaubah 9:105)

Shihab dalam Tafsir Al-Misbah (2002:237) menjelaskan bahwa:

"Katakan kepada manusia, wahai Rasulullah, "Bekerjalah kalian dan jangan segan-segan melakukan perbuatan baik dan melaksanakan kewajiban. Sesungguhnya Allah mengetahui segala pekerjaan kalian, dan Rasulullah serta orangorang mukmin akan melihatnya. Mereka akan menimbangnya dengan timbangan keimanan dan bersaksi dengan perbuatanperbuatan itu. Kemudian setelah mati, kalian akan dikembalikan kepada Yang Maha Mengetahui lahir dan batin kalian, Ialu mengganjar dengan perbuatanperbuatan kalian setelah Dia memberitahu kalian segala hal yang kecil dan besar dari perbuatan kalian itu"

Ayat diatas dapat menjadi motivasi umat muslim untuk selalu bekerja dan berjuang mendapatkan harta dengan jalan yang baik dan halal, tidak menggunakan cara-cara yang batil, tidak mendzalimi dan terhindar dari unsur riba, maysir (perjudian) dan gharar. Maka investasi syariah merupakan salah satu alternatif untuk memutar modal/harta yang dimiliki saat ini sehingga mendatangkan return di masa yang akan datang, karena tidak seorang pun di muka bumi ini yang dapat mengetahui apa yang akan diperbuat, diusahakan, serta kejadian apa yang akan terjadi pada hari esok. Adanya ketidakpastian di masa depan ini mendorong manusia untuk berinvestasi.

Instrumen investasi yang banyak dipilih para investor saat berinvestasi di pasar modal adalah saham, karena saham mampu memberikan tingkat keuntungan yang menarik. Saham merupakan sertifikat yang menunjukkan bukti kepemilikan suatu perusahaan (Tandelilin, 2010: 32). Saham merupakan salah satu bentuk investasi yang diperbolehkan dalam Islam. Saham merupakan surat berharga bukti penyertaan modal pada suatu perusahaan, dimana modal yang ditanamkan tersebut akan di kelola oleh perusahaan untuk menghasilkan keuntungan, dengan bukti penyertaan modal tersebut maka pemegang saham berhak untuk mendapatkan bagian hasil dari usaha perusahaan tersebut dalam bentuk dividen. Konsep penyertaan modal dengan hak bagi hasil usaha ini merupakan konsep yang tidak bertentangan dengan prinsip syariah. Prinsip syariah mengenal konsep ini sebagai kegiatan musyarakah atau syirkah (LPKS, 2015). Oleh sebab itu, sebaiknya para investor muslim lebih memilih membeli saham dari emiten yang kegiatan usahanya tidak bertentangan dengan syariah, agar investasi yang dilakukan lebih membawa berkah.

Pada 3 Juli 2000, Bursa Efek Indonesia (BEI) bersama PT. Danareksa 
Adityasari, et al/ Jurnal Ekonomi Syariah Teori dan Terapan Vol. 5 No. 5 Mei 2018: 420-432; DeterMINAN KEBIJAKAN DIVIDEN PADA PERUSAHAAN MANUFAKTUR DI JAKARTA ISLAMIC INDEX

Investment Management menerbitkan Jakarta Islamic Index untuk mempermudah investor muslim dalam melakukan investasi pada saham yang berbasis syariah. Jakarta Islamic Index menjadi tolok ukur (benchmark) dalam mengukur kinerja suatu investasi pada saham dengan basis syariah. Jakarta Islamic Index terdiri dari 30 saham yang dipilih dari saham-saham yang sesuai dengan syariat Islam dan dievaluasi periodik setiap 6 bulan yaitu setiap Juni dan Desember atau berdasarkan periode yang ditetapkan oleh Bapepam-LK yaitu pada saat diterbitkannya Daftar Efek Syariah. Sedangkan perubahan jenis usaha emiten akan dimonitor secara terus menerus berdasarkan data publik yang tersedia (www.idx.co.id).

Investor menanamkan modalnya pada saham sebuah perusahaan memiliki tujuan untuk memperoleh pendapatan atau return. Return dari investasi saham dapat berupa pendapatan dividen maupun capital gain (loss). Dividen merupakan pendapatan yang diperoleh setiap periode selama saham masih dimiliki, dan capital gain merupakan pendapatan dari selisih harga jual saham terhadap harga beli apabila saham di jual di pasar sekunder (Kusuma, 2004:102).

Bagi investor, dividen merupakan salah satu harapan terbesar terhadap investasi yang telah dilakukannya, dan investor muslim yang memilih untuk berinvestasi pada saham syariah harus paham hakikat dari kegiatan investasi yang dilakukannya, Ryandono (2009:70) menyatakan bahwa return investasi dalam Islam adalah sesuai dengan besarnya sumber daya yang dikorbankan dan Islam selalu mengajarkan untuk mendahulukan perintah Allah dan menjauhi larangan-Nya.

Fungsi manajemen keuangan dalam perusahaan adalah menentukan tiga keputusan yaitu: keputusan investasi, keputusan pendanaan dan keputusan dividen. Tugas manajemen keuangan untuk menetapkan kebijakan dividen perusahaan merupakan bagian yang tidak dapat dipisahkan dengan keputusan pendanaan dan keputusan investasi perusahaan. Hal ini karena kebijakan dividen yang diputuskan oleh manajemen akan mempengaruhi harga saham, kesempatan investasi, struktur kevangan, arus pendanaan dan posisi likuiditas perusahaan (Nurmala,2006:18). Kebijakan dividen merupakan keputusan untuk menetapkan besarnya persentase laba bersih perusahaan yang dibagikan kepada pemegang saham sebagai dividen tunai yang disebut sebagai dividend payout ratio dan sisanya merupakan persentase laba ditahan perusahaan (Brigham, 2006:69).

Dalam penentuan besarnya dividen yang akan dibagikan kepada pemegang saham diperlukan kebijakan dengan memperhatikan faktor-faktor tertentu dari pihak yang berkepentingan, yaitu manajemen serta pemegang saham perusahaan. Selain itu kebijakan dividen juga menjadi bagian penting dari strategi pendanaan jangka panjang perusahaan 
Adityasari, et al/ Jurnal Ekonomi Syariah Teori dan Terapan Vol. 5 No. 5 Mei 2018: 420-432; DeterMINAN KEBIJAKAN DIVIDEN PADA PERUSAHAAN MANUFAKTUR DI JAKARTA ISLAMIC INDEX

dalam menyikapi dinamika lingkungan bisnisnya (Sudarsi, 2002)

Menurut Hanafi (2004:375) beberapa faktor yang memengaruhi kebijakan dividen antara lain: kesempatan investasi, likuiditas dan profitabilitas, akses ke pasar kevangan, stabilitas pendapatan, dan aturan pembatasan dari kreditur, sedangkan Menurut Riyanto (2001:267) beberapa faktor yang memengaruhi kebijakan dividen antara lain : posisi likuiditas perusahaan, kebutuhan dana untuk membayar hutang, pengawasan perusahaan dan tingkat pertumbuhan perusahaan. Terdapat berbagai macam faktor yang dapat mempengaruhi perusahaan dalam menetapkan dividend payout ratio menurut berbagai pakar sebagaimana telah dipaparkan di atas. Adapun dalam penelitian ini, optimalisasi kebijakan dividen dipertimbangkan oleh beberapa faktor diantaranya: ukuran perusahaan (firm size), profitabilitias, solvabilitas dan risiko sistematis ( $\beta$ ).

\section{RUMUSAN MASALAH}

Berdasarkan uraian latar belakang di atas maka rumusan masalah yang dapat dibuat adalah:

1. Apakah secara parsial Ukuran Perusahaan,Profitabilitas, Solvabilitas dan Risiko Sistematis berpengaruh terhadap Kebijakan Dividen perusahaan manufaktur di Jakarta Islamic Index pada periode 2009-2015?

2. Apakah secara simultan Ukuran Perusahaan,Profitabilitas, Solvabilitas dan Risiko Sistematis berpengaruh terhadap Kebijakan Dividen perusahaan manufaktur yang terdaftar di Jakarta Islamic Index pada periode 2009-2015?

\section{LANDASAN TEORI}

\section{Investasi Syariah}

Dalam Islam, investasi memiliki definisi dan tujuan yang lebih luas karena mencakup aspek dunia (materi) dan akhirat (ukhrawi) seperti yang dijelaskan oleh Ryandono (2009:70) bahwa Investasi yang islami adalah pengorbanan sumber daya pada masa sekarang untuk mendapatkan hasil yang pasti, dengan harapan memperoleh hasil yang lebih besar dimasa yang akan datang, baik langsung maupun tidak langsung seraya tetap berpijak pada prinsip-prinsip syariah Islam secara menyeluruh (kaffah). Selain itu, semua bentuk investasi dilakukan dalam rangka ibadah kepada Allah untuk mencapai kebahagiaan lahir batin di dunia dan akhirat baik generasi sekarang maupun generasi yang akan datang.

\section{Saham Syariah}

Produk investasi saham pada prinsipnya sudah sesuai dengan prinsip Islam. Ditinjau dari prinsip ekonomi Islam, syirkah atau musyarakah merupakan suatu akad kerjasama antara dua atau lebih pihak untuk melakukan usaha bersama dimana masing-masing pihak menyetorkan sejumlah dana, barang atau jasa untuk memperoleh keuntungan bagi kepentingan bersama (Sutedi, 2011:91). Selain itu OJK telah membuat regulasi tentang Kriteria dan Penerbitan Daftar Efek Syariah diatur pada Peraturan 
Adityasari, et al/ Jurnal Ekonomi Syariah Teori dan Terapan Vol. 5 No. 5 Mei 2018: 420-432; DeterMINAN KEBIJAKAN DIVIDEN PADA PERUSAHAAN MANUFAKTUR DI JAKARTA ISLAMIC INDEX

No.Il.K.1 serta Persyaratan dan Penerbitan Saham Syariah oleh Emiten Syariah atau Perusahaan Publik Syariah diatur dalam POJK No.17/POJK.04/2015

\section{Dividen}

Dividen merupakan pembagian laba perusahaan kepada para pemegang saham setiap periode yang besarnya sebanding dengan jumlah saham yang dimiliki (Hartono,2010 : 201)

\section{Kebijakan Dividen}

Kebijakan dividen (dividend policy) merupakan keputusan apakah laba yang diperoleh perusahaan pada akhir tahun akan dibagikan kepada pemegang saham dalam bentuk dividen atau akan ditahan untuk menambah modal guna pembiayaan investasi di masa yang akan datang (Martono dan Harjito, 2005: 253). Dividend payout ratio merupakan salah satu komponen dasar dari kebijakan dividen suatu perusahaan. Dividend payout ratio menunjukkan prosentase laba bersih perusahaan yang dibagikan kepada para pemegang saham dalam bentuk dividen kas (Bringham,2006:69)

\section{Teori Kebijakan Dividen}

\section{The Bird in Hand Theory}

Teori ini dikemukakan oleh Myron Gordon dan John Lintner (1963) yang menyatakan bahwa nilai perusahaan akan di maksimalkan dengan menentukan rasio pembagian dividen yang tinggi. Investor lebih merasa aman untuk memperoleh pendapatan berupa pembayaran dividen daripada menunggu capital gain. Berdasarkan teori ini, investor percaya bahwa pendapatan dividen memiliki nilai yang lebih besar dibandingkan dengan capital gain, karena dividen memiliki tingkat kepastian yang lebih tinggi dibandingkan dengan capital gain.

\section{Residual Dividend Theory}

Berdasarkan teori residual oleh Elton dan Gruber (1970), bahwa kebijakan perusahaan untuk membayarkan dividen merupakan prioritas terakhir apabila perusahaan mempunyai dana sisa. Pembayaran dividen dilakukan setelah perusahaan memenuhi kebutuhan pendanaan untuk investasi yang menguntungkan bagi perusahaan.

\section{Signaling Hypothesis Theory}

Signalling Theory (Teori Sinyal) pertama kali dikemukakan oleh Spence (1973), bahwa investor menganggap perubahan dividen sebagai isyarat dari perkiraan manajemen atas laba. Suatu kenaikan dividen yang lebih tinggi daripada yang diperkirakan merupakan sinyal bagi investor bahwa manajemen perusahaan memperkirakan peningkatan laba di masa mendatang, begitu pula sebaliknya.

\section{Clientele effect}

Teori ini pertama kali dikemukakan oleh Black dan Scholes (1974) bahwa kelompok pemegang saham akan memiliki preferensi yang berbeda-beda terhadap kebijakan dividen perusahaan. Clientele effect merupakan kecenderungan suatu perusahaan untuk menarik sekelompok investor yang menyukai kebijakan dividennya, karena erusahaan tidak dapat mengganti-ganti kebijakan dividennya dengan mudah karena tidak efisien. 
Adityasari, et al/ Jurnal Ekonomi Syariah Teori dan Terapan Vol. 5 No. 5 Mei 2018: 420-432; DeterMINAN KEBIJAKAN DIVIDEN PADA PERUSAHAAN MANUFAKTUR DI JAKARTA ISLAMIC INDEX

\section{HIPOTESIS PENELITIAN}

\section{Pengaruh Ukuran Perusahaan terhadap} Kebijakan Dividen

Ukuran perusahaan (Firm Size) merupakan skala besar kecilnya perusahaan yang dapat diukur dari besarnya natural logarithm (In) dari tenaga kerja, kapitalisasi pasar (market capitalization), total asset, dan total penjualan perusahaan (Al-Malkawi, 2008). Perusahaan berskala besar akan memiliki akses lebih untuk meningkatkan pendanaan eksternal melalui pasar modal dengan biaya yang rendah dan sedikit kendala dibandingkan dengan perusahaan yang berukuran kecil (Al Malkawi, 2008). Berdasarkan Signaling Theory, Ukuran perusahaan (size) yang besar dan terus bertumbuh bisa merefleksikan tingkat profit mendatang perusahaan, hal ini dapat ditangkap investor sebagai sinyal positif dan prospek perusahaan yang baik sehingga dapat memberikan pengaruh yang positif terhadap nilai perusahaan. Maka Perusahaan berskala besar cenderung memberikan ketertarikan sendiri bagi investor untuk berinvestasi pada perusahaan tersebut. Hal ini dapat mengurangi ketergantungan perusahaan pada pendanaan internal dan cenderung akan meningkatkan rasio pembayaran dividen, untuk mempertahankan investor yang menyukai kebijakan dividennya dan menarik investor baru untuk berinvestasi diperusahaan tersebut, sesuai dengan teori clientile effect.
$\mathrm{H}_{1}$ : Ukuran Perusahaan berpengaruh positif terhadap Kebijakan Dividen

\section{Pengaruh Profitabilitas terhadap Kebijakan Dividen}

Perusahaan yang mempunyai profitabilitas yang tinggi akan menarik minat investor untuk menanamkan modalnya dengan harapan akan mendapatkan retrun yang tinggi pula. Oleh karena itu deviden yang diambil dari keuntungan bersih setelah pajak yang akan mempengaruhi rasio pembayaran dividen. Perusahaan yang semakin besar keuntungannya akan membayar porsi pendapatan yang semakin besar sebagai deviden (Sudarsi 2002:79).

$\mathrm{H}_{2}$ : Profitabilitas (ROE) berpengaruh positif terhadap Kebijakan Dividen.

3. Pengaruh Solvabilitas terhadap Kebijakan

\section{Dividen}

Solvabilitas menunjukkan proporsi atau penggunaan utang untuk membiayai investasi perusahaan (Sartono, 2001:120) Penggunaan utang yang terlalu besar dalam kegiatan operasional perusahaan memberikan dampak yang kurang baik terhadap perusahaan karena perusahaan harus membayar kewajibankewajibannya yang nantinya akan mengurangi keuntungan yang diperoleh. Apabila perusahaan menentukan bahwa pelunasan utangnya akan diambilkan dari laba ditahan, berarti perusahaan harus menahan sebagian besar dari laba bersih perusahaan untuk keperluan tersebut, yang ini berarti berarti hanya sebagian kecil saja yang laba bersih yang dapat dibayarkan sebagai deviden (Riyanto 
Adityasari, et al/ Jurnal Ekonomi Syariah Teori dan Terapan Vol. 5 No. 5 Mei 2018: 420-432; DeterMINAN KEBIJAKAN DIVIDEN PADA PERUSAHAAN MANUFAKTUR DI JAKARTA ISLAMIC INDEX

2001:267). Maka berlaku hubungan yang negatif atau berlawanan. Artinya semakin tinggi rasio solvabilitas maka pembayaran dividen akan semakin kecil.

$\mathrm{H}_{3}$ : Solvabilitas berpengaruh negatif terhadap Kebijakan Dividen.

\section{Pengaruh Risiko Sistematis $(\beta)$ terhadap}

\section{Kebijakan Dividen}

Risiko sistematis atau dikenal dengan risiko pasar merupakan risiko umum yang berkaitan dengan perubahan yang terjadi dipasar secara keseluruhan seperti inflasi, resesi, tingkat suku bunga yang tinggi, kerusuhan maupun perubahan politik. Fluktuasi pasar tersebut biasanya ditunjukkan oleh berubahnya indeks pasar saham secara keseluruhan (Tandelilin, 2010:104-105). Berdasarkan signaling theory, ketika risiko sistematis tinggi, sebagian besar dari investor risk averse akan ragu untuk berinvestasi bahkan menjual sahamnya karena tidak ingin mengambil risiko tinggi atas investasinya. Menurut konsep teori risk and return yang menjelaskan bahwa semakin tinggi tingkat risiko yang dihadapi perusahaan, maka investor akan menuntut perusahaan untuk memberikan return yang tinggi. Namun dibutuhkan modal yang besar untuk memberikan dividen yang besar terlebih ketika terjadi krisis, resesi dan risiko sistematis yang tinggi, perusahaan akan lebih hati-hati dalam menggunakan dananya, dan pada kenyataannya tidak ada jaminan bahwa saham yang ditanamkan saat risiko sistematis sedang tinggi dapat berhasil atau bahkan dapat gagal karena risiko yang mereka ambil terlalu tinggi. Sehingga ketika risiko pasar $(\beta)$ suatu perusahaan tinggi, investor akan ragu menanam saham di perusahaan tersebut. Semakin besar risiko sistematis ( $\beta$ ), akan semakin kecil kemungkinan perusahaan untuk mendapatkan dana eksternal. Dengan demikian, perusahaan harus menggunakan dana internal yang berasal dari laba ditahan untuk membiayai operasional dan kebutuhan investasi perusahaan sehingga akan mengurangi rasio pembayaran dividen kepada pemegang saham (Suwaldiman dan Aziz, 2006)

\section{$\mathrm{H}_{4} \quad$ : Risiko Sistematis $(\beta)$ berpengaruh negatif terhadap Kebijakan Dividen \\ $\mathrm{H}_{5}$ : Ukuran Perusahaan, Profitabilitas, Solvabilitas dan Risiko Sistematis ( $\beta$ ) secara simultan berpengaruh signifikan terhadap Kebijakan Dividen.}

\section{METODE PENELITIAN}

\section{Pendekatan Penelitian}

Penelitian ini bertujuan untuk mengetahui hubungan antar variabel yang didasarkan pada hipotesis yang telah diungkapkan sebelumnya. Variabel ukuran perusahaan, profitabilitas, solvabilitas dan risiko sistematis akan diuji pengaruhnya terhadap variabel dependen yaitu kebijakan dividen perusahaan manufaktur di Jakarta Islamic Index dengan metode regresi data panel dengan menggunakan software Eviews 8.0.

\section{Definisi Operasional Variabel}

\begin{tabular}{|c|c|}
\hline Variabel & Proksi \\
\hline Kebijakan Dividen & DPR $=\frac{\text { Dividend per Share }}{\text { Earning per Share }}$ \\
\hline
\end{tabular}


Adityasari, et al/ Jurnal Ekonomi Syariah Teori dan Terapan Vol. 5 No. 5 Mei 2018: 420-432; DeterMINAN KEBIJAKAN DIVIDEN PADA PERUSAHAAN MANUFAKTUR DI JAKARTA ISLAMIC INDEX

\begin{tabular}{|l|c|}
\hline Ukuran Perusahaan & Ln Total Asset \\
\hline Profitabilitas & ROE $=\frac{\text { EAT }}{\text { Equity }}$ \\
\hline Solvabilitas & DER $=\frac{\text { Total Utang (Debt) }}{\text { Equity }}$ \\
\hline Risiko Sistematis & $R_{i t}=a_{i}+\beta_{i t} R_{m t}+e_{i t}$ \\
\hline
\end{tabular}

\section{Jenis dan Sumber Data}

Data dalam penelitian ini adalah data sekunder berupa berupa laporan keuangan tahunan (annual report) yang di peroleh dari website resmi masingmasing perusahaan dan company report yang diterbitkan oleh Bursa Efek Indonesia.

\section{Populasi dan Sampel}

Populasi dalam penelitian ini adalah Perusahaan Manufaktur terdaftar di Jakarta Islamic Index pada periode tahun 2009-2015. Sampel data dalam penelitian ini ditentukan menggunakan teknik non-probability purposive sampling dan terdapat 5 Perusahaan manufaktur di Jakarta Islamic Index yang memenuhi kriteria pengambilan sampel.

\section{Teknik Analisis Data}

\section{Estimasi Model Regresi Data Panel}

Terdapat tiga pendekatan yang dapat digunakan untuk mengestimasi data panel, antara lain Common Effect Model (Pooled Least Square/Ordinary Least Square), Fixed EffectModel (FEM) dan Random Effect Model (REM).

\section{Pemilihan Model Regresi Data Panel}

Ketiga model estimasi diatas yaitu Common Effect Model, Fixed Effect Model dan Random Effect Model akan dilakukan pemilihan model estimasi terbaik yang paling sesuai dengan data penelitian.
Pemilihan Model estimasi terbaik dilakukan dengan beberapa metode pengujian, yaitu Uji Chow (Uji F Restriced) dan Uji Haussman (Ajija, 2011 : 53)

\section{a. Uji Chow (Uji F)}

Uji Chow digunakan untuk memilih model estimasi antara Common Effect Model (CEM) atau Fixed Effect Model (FEM) yang paling sesuai. Hipotesis yang digunakan dalam uji ini yaitu :

$\mathrm{H}_{0}$ : Model menggunakan CEM

$\mathrm{H}_{1}$ : Model menggunakan FEM

Kriteria pengujian hipotesis dengan menggunakan taraf signifikansi $5 \%$ (a = $0,05)$ dan melihat nilai probabilitas CrossSection $F$ pada Uji Chow. Apabila nilai Cross-Section $F<0,05$ maka keputusan pengujian adalah $\mathrm{H}_{0}$ ditolak dan $\mathrm{H}_{1}$ diterima dan apabila nilai probabilitas Cross-Section $\mathrm{F}>0,05$ maka $\mathrm{H}_{0}$ diterima.

\section{b. Uji Haussman}

Uji ini digunakan untuk memilih model estimasi antara Fixed Effect Model (FEM) atau Random Effect Model (REM) yang paling sesuai. Hipotesis yang digunakan dalam uji ini yaitu :

$\mathrm{H}_{0}$ : Model menggunakan REM

$\mathrm{H}_{1}$ : Model menggunakan FEM

Kriteria pengujian hipotesis dengan menggunakan tingkat signifikansi $5 \%$ $(a=0,05)$ dan melihat nilai probabilitas Cross-section Random pada hasil Uji Hausman. Apabila nilai prob. CrossSection Random < 0,05 maka keputusan pengujian adalah $\mathrm{H}_{0}$ ditolak dan apabila nilai prob. Cross-Section Random $>0,05$ 
Adityasari, et al/ Jurnal Ekonomi Syariah Teori dan Terapan Vol. 5 No. 5 Mei 2018: 420-432; DeterMINAN KEBIJAKAN DIVIDEN PADA PERUSAHAAN MANUFAKTUR DI JAKARTA ISLAMIC INDEX

maka keputusan pengujian adalah menerima $\mathrm{H}$.

\section{Uji Hipotesis}

\section{Uji Parsial (Uji t)}

Uji $†$ digunakan untuk melihat seberapa jauh pengaruh masingmasing variabel bebas dapat menerangkan variabel terikat secara parsial.

\section{Uji Simultan (Uji F)}

Uji $F$ digunakan untuk menguji pengaruh variabel independen yang digunakan dalam model analisis secara simultan (bersama-sama) terhadap variabel dependen.

\section{Uji Koefisien Determinasi $\left(\mathbf{R}^{2}\right)$}

Uji Koefisien Determinasi $\left(R^{2}\right)$ merupakan pengujian yang dimaksudkan untuk mengetahui sejauh mana model regresi dapat menjelaskan variabel dependennya. Nilai Koefisien Determinasi $\left(R^{2}\right)$ terletak diantara angka 0 (nol) dan 1 (satu) $(0<\mathrm{R} 2<1$. Ketika nilai Koefisien Determinasi $\left(R^{2}\right)$ mendekati angka 1 maka semakin baik model regresi. Ketika $R^{2}$ sama dengan angka satu maka variabel dependen 100 persen dapat diterangkan oleh variabel independen dan sebaliknya (Sarwoko, 2005: 53)

\section{HASIL DAN PEMBAHASAN}

\section{Statistik Deskriptif}

Tabel Statistik Deskriptif Variabel

\begin{tabular}{|c|c|c|}
\hline \multirow{4}{*}{$\begin{array}{c}\text { Kebijakan } \\
\text { Dividen }\end{array}$} & Mean & 56.64771 \\
\hline & Min & 25.77000 \\
\hline & Max & 100.0600 \\
\hline & $S D$ & 24.88976 \\
\hline \multirow{4}{*}{$\begin{array}{c}\text { Ukuran } \\
\text { Perusahaan }\end{array}$} & Mean & 10.10686 \\
\hline & Min & 8.780000 \\
\hline & Max & 12.41000 \\
\hline \multirow{2}{*}{\multicolumn{2}{|c|}{\begin{tabular}{l|l} 
\\
\end{tabular}}} & 1.080996 \\
\hline & & \begin{tabular}{|l|l|}
4829 &
\end{tabular} \\
\hline
\end{tabular}

\begin{tabular}{|c|l|c|}
\hline \multirow{5}{*}{ Solvabilitas } & Min & 12.34000 \\
\cline { 2 - 3 } & Max & 125.8100 \\
\cline { 2 - 3 } & SD & 36.25185 \\
\hline \multirow{4}{*}{$\begin{array}{c}\text { Risiko } \\
\text { Sistematis }\end{array}$} & Mean & 0.725429 \\
\cline { 2 - 3 } & Min & 0.150000 \\
\cline { 2 - 3 } & Max & 2.260000 \\
\cline { 2 - 3 } & SD & 0.653157 \\
\hline & Mean & 1.168722 \\
\cline { 2 - 3 } & Max & 0.201203 \\
\cline { 2 - 3 } & SD & 1.903601 \\
\hline
\end{tabular}

\section{Pemilihan Model Estimasi Data Panel}

Pemilihan model estimasi pada model regresi data panel dilakukan dengan melakukan beberapa pengujian untuk memilih model estimasi yang terbaik, dengan melakukan Uji Chow (untuk memilih antara CEM dan FEM) dan Uji Haussman (untuk memilih antara FEM dan REM) .

\section{Uji Chow}

Uji Chow dilakukan untuk menentukan model terbaik antara CEM dengan FEM. Dengan menggunakan alfa $0,05(a=5 \%)$ dan melihat nilai probabilitas CrossSection. Apabila nilai Cross-Section $<0,05$ maka keputusan pengujian adalah $\mathrm{H}_{0}$ ditolak dan sebaliknya.

$$
\begin{aligned}
\mathrm{H}_{0}= & \text { Permodelan Kebijakan Dividen } \\
& \text { adalah CEM } \\
\mathrm{H}_{\mathrm{a}=}= & \text { Permodelan Kebijakan Dividen } \\
& \text { adalah FEM }
\end{aligned}
$$

\section{Tabel Uji Chow}

\begin{tabular}{lrrr} 
Effects Test & Statistic & d.f. & Prob. \\
\hline \hline Cross-section F & 3.163267 & $(4,26)$ & 0.0303 \\
Cross-section Chi-square & 13.878538 & 4 & 0.0077
\end{tabular}

Berdasarkan hasil Uji Chow pada tabel diatas nilai probabilitas Cross-Section $F$ adalah sebesar 0,0303 dengan tingkat signifikansi $0,05 \quad(a=5 \%) \quad H_{0}$ ditolak dan $\mathrm{H}_{1}$ diterima, dengan demikian model yang 
Adityasari, et al/ Jurnal Ekonomi Syariah Teori dan Terapan Vol. 5 No. 5 Mei 2018: 420-432; DeterMINAN KEBIJAKAN DIVIDEN PADA PERUSAHAAN MANUFAKTUR DI JAKARTA ISLAMIC INDEX

terbaik adalah Fixed Effect Model. Selanjutnya perlu dilakukan uji Hausman untuk memilih model estimasi terbaik antara FEM dan REM.

\section{Uji Haussman}

Setelah dilakukan uji Chow dengan hasil model terbaik adalah FEM, maka selanjutnya perlu dilakukan uji Haussman untuk mendapatkan hasil yang optimal dengan menggunakan tingkat signifikansi $5 \%(a=0,05)$ dan melihat nilai probabilitas Cross-Section Random pada hasil Uji Haussman.

$\mathrm{H}_{0}=$ Permodelan Kebijakan Dividen
adalah

Random Effect Model

$\mathrm{H}_{\mathrm{a}}=$ Permodelan Kebijakan Dividen adalah Fixed Effect Model

\section{Tabel Uji Haussman}

\begin{tabular}{lrrr} 
Test Summary & $\begin{array}{r}\text { Chi-Sq. } \\
\text { Statistic }\end{array}$ & $\begin{array}{r}\text { Chi-Sq. } \\
\text { d.f. }\end{array}$ & Prob. \\
\hline \hline Cross-section random & 12.653069 & 4 & 0.0131
\end{tabular}

Berdasarkan hasil Uji Haussman pada tabel diatas, nilai probabilitas CrossSection Random sebesar 0,0131 lebih kecil dari tingkat signifikansi $5 \% \quad(a=0,05)$. Berdasarkan hasil Uji Haussman pada tabel diatas, maka dapat disimpulkan bahwa $\mathrm{H}_{0}$ ditolak dan $\mathrm{H}_{1}$ diterima, maka model terbaik adalah Fixed Effect Model (FEM)

\section{Uji Hipotesis}

Berdasarkan Uji Chow dan Uji Haussman yang telah dilakukan, model terbaik yang sesuai dengan data penelitian ini adalah Fixed Effect Model (FEM). Hasil pengolahan data dengan Fixed Effect Model disajikan dalam tabel berikut yang memuat hasil Uji $t$, uji $F$ dan koefisien determinasi.

\section{Tabel Hasil Regresi Fixed Effect Model}

\begin{tabular}{crr} 
Variable & Coefficient & Prob. \\
\hline \hline C & -241.3238 & 0.0457 \\
SIZE & 27.76533 & 0.0178 \\
ROE & 1.820280 & 0.0197 \\
DER & -86.26624 & 0.0146 \\
RISK & 4.148028 & 0.5249 \\
Fixed Effect (Cross) & & \\
ASII-C & -10.16678 & \\
INTP_C & -20.97645 & \\
KLBF-C & 11.44674 & \\
SMGR-C & -13.06128 & \\
UNVR-C & 32.75778 & \\
R-squared & 0.831356 & \\
Adjusted R-squared & 0.779466 & \\
F-statistic & 16.02137 & \\
Prob(F-statistic) & 0.000000 &
\end{tabular}

Sehingga dapat disusun persamaan model regresi sebagai berikut:

$\mathrm{DPR}_{\mathrm{it}}=-241.3238+27.76533 \mathrm{SIZE}_{\mathrm{it}}+1.820280 \mathrm{PROF}_{\mathrm{it}}$ $-86.26624 \mathrm{SOLV}_{\text {it }}+4.148028 \mathrm{RISK}_{\text {it }}$

\section{Uji † (parsial)}

Uji $\dagger$ dilakukan untuk mengetahui pengaruh variabel independen secara individual terhadap variabel dependen. Dari tabel diatas, maka pengambilan keputusan hipotesis sebagai berikut:

1. Variabel Ukuran Perusahaan memiliki nilai probabilitas sebesar 0.0178 lebih kecil dari tingkat signifikansi $5 \%(a=0,05)$ sehingga $\mathrm{H}_{0}$ ditolak dan $\mathrm{H}_{1}$ diterima. Maka terdapat pengaruh signifikan antara Ukuran Perusahaan terhadap Kebijakan Dividen. nilai koefisien sebesar 27.76533 menunjukkan bahwa setiap kenaikan sebesar satu satuan ukuran perusahaan maka dividend 
Adityasari, et al/ Jurnal Ekonomi Syariah Teori dan Terapan Vol. 5 No. 5 Mei 2018: 420-432; DeterMINAN KEBIJAKAN DIVIDEN PADA PERUSAHAAN MANUFAKTUR DI JAKARTA ISLAMIC INDEX

payout ratio juga meningkat sebesar 27,76533 dengan asumsi bahwa variabel yang lain adalah konstan.

2. Variabel Profitabilitas (ROE) memiliki nilai probabilitas sebesar 0,0197 lebih kecil dari 0,05 sehingga $\mathrm{H}_{0}$ ditolak dan $\mathrm{H}_{2}$ diterima. Hal ini menunjukkan terdapat pengaruh signifikan antara Profitabilitas yang diproksikan dengan Return on Equity (ROE) terhadap Kebijakan Dividen. Nilai koefisien variabel profitabilitas adalah sebesar 1,820280 menunjukkan bahwa setiap kenaikan sebesar satu satuan profitabilitas (ROE) maka dividen payout ratio perusahaan juga meningkat sebesar 1,820280 dengan asumsi bahwa variabel yang lain adalah konstan.

3. Variabel Solvabilitas (DER) memiliki nilai probabilitas sebesar 0,0146 lebih kecil dari 0,05 sehingga $\mathrm{H}_{0}$ ditolak dan $\mathrm{H}_{3}$ diterima. Hal ini menunjukkan bahwa terdapat pengaruh signifikan antara Solvabilitas yang diproksikan dengan Debt to Equity Ratio (DER) terhadap Kebijakan Dividen perusahaan. Nilai koefisien variabel solvabilitas adalah sebesar -86,26624 menunjukkan bahwa setiap kenaikan sebesar satu satuan solvabilitas (DER) maka dividend payout ratio menurun sebesar 86,26624 , dengan asumsi bahwa variabel yang lain adalah konstan.

4. Variabel Risiko Sistematis ( $\beta$ ) memiliki nilai probabilitas sebesar 0,5249 tidak signifikan pada tingkat signifikansi $5 \%$ sehingga $\mathrm{H}_{0}$ diterima dan $\mathrm{H}_{4}$ ditolak.
Dengan demikian Risiko Sistematis $(\beta)$ memiliki pengaruh tidak signifikan terhadap kebijakan dividen perusahaan manufaktur di Jakarta Islamic Index pada periode 2009-2015.

\section{Uji Simultan (F)}

Uji F digunakan untuk menguji pengaruh secara simultan variabel independen terhadap variabel dependen. Berdasarkan tabel diatas nilai probabilitas F-Statistik adalah sebesar 0.000000 lebih kecil dari tingkat signifikansi $5 \% \quad(a=0,05)$ sehingga $\mathrm{H}_{0}$ ditolak dan $\mathrm{H}_{1}$ diterima. Maka dapat disimpulkan bahwa variabel independen, yaitu ukuran perusahaan, profitabilitas, solvabilitas dan risiko sistematis ( $\beta$ ) secara simultan (bersamasama) berpengaruh signifikan terhadap variabel dependen, yaitu kebijakan dividen perusahaan manufaktur di Jakarta Islamic Index periode 2009-2015.

\section{Uji Koefisien Determinasi ( $\left.\mathbf{R}^{2}\right)$}

Uji Koefisien determinasi bertujuan untuk mengetahui seberapa besar variabel independen dapat menjelaskan variabel dependen. Hasil pengolahan data yang disajikan pada tabel diatas diperoleh nilai Adjusted R-Squared sebesar 0,779466. Model estimasi yang baik adalah model estimasi yang mempunyai $\mathrm{R}^{2}$ mendekati angka 1, maka nilai Adjusted R-Square pada penelitian ini cukup baik. Sehingga dapat disimpulkan bahwa variabel independen yang digunakan dalam penelitian ini dapat menjelaskan $77,95 \%$ variabel dependen dan 22,05\% 
Adityasari, et al/ Jurnal Ekonomi Syariah Teori dan Terapan Vol. 5 No. 5 Mei 2018: 420-432; DeterMINAN KEBIJAKAN DIVIDEN PADA PERUSAHAAN MANUFAKTUR DI JAKARTA ISLAMIC INDEX

dipengaruhi oleh variabel selain variabel yang digunakan dalam penelitian ini.

\section{SIMPULAN}

Berdasarkan hasil analisis dan interpretasi data yang dilakukan maka dapat diambil kesimpulan sebagai berikut:

1. Ukuran perusahaan (firm size) secara parsial berpengaruh positif dan signifikan terhadap kebijakan dividen perusahaan manufaktur di Jakarta Islamic Index pada periode 2009-2015.

2. Profitabilitas secara parsial berpengaruh positif dan signifikan terhadap kebijakan dividen perusahaan manufaktur di Jakarta Islamic Index pada periode 2009-2015.

3. Solvabilitas secara parsial berpengaruh negatif dan signifikan terhadap kebijakan dividen perusahaan manufaktur di Jakarta Islamic Index pada periode 2009-2015.

4. Risiko sistematis secara parsial berpengaruh tidak signifikan terhadap kebijakan dividen perusahaan manufaktur di Jakarta Islamic Index pada periode 2009-2015, pada tingkat signifikansi 5\% $(a=0,05)$.

5. Ukuran perusahaan, profitabilitas, solvabilitas dan risiko sistematis secara simultan berpengaruh signifikan terhadap kebijakan dividen perusahaan manufaktur di Jakarta Islamic Index pada periode 2009-2015, pada tingkat kepercayaan $95 \%$ (a= $0,05)$.

\section{DAFTAR PUSTAKA}

Al-Malkawi. 2008. Husam-Aldin Nizar. Factors Influencing Corporate Dividend Decision : Evidendce from Jordanian Panel Data. International Journal of Bussiness, Vol.13, No.2, pp.177-195

Brigham, Eugene F dan Joel F. Houston. 2006. Dasar - dasar Manajemen Keuangan. Buku 1, Edisi Kesepuluh. Jakarta : Salemba Empat.

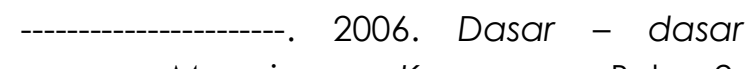
Manajemen Keuangan. Buku 2, Edisi Kesepuluh, Jakarta : Salemba Empat.

Gujarati, Damodar. 2003. Ekonometrika Dasar. Edisi Keenam. Jakarta: Erlangga

Gujarati, Damodar N dan Dawn C. Porter. 2013. Dasar- dasar Ekonometrika. Buku 2. Edisi Kelima. Jakarta: Salemba Empat.

Hanafi, M. Mamduh. 2004.Manajemen Keuangan. Yogyakarta: BPFE

Hartono, Jogiyanto, 2010. Teori Portofollio dan Analisis Investasi, Edisi Ketujuh. Yogyakarta: BPFE Yogyakarta

Kasmir. 2015. Analisis Laporan Keuangan. Edisi Kedelapan, Jakarta : Rajawali Pers

Kementerian Agama Republik Indonesia. 2013. Al-Qur'an dan Terjemahannya. Solo : PT Tiga Serangkai Pustaka Mandiri.

Martono dan D. Agus Harjito. 2005. Manajemen Kevangan. Yogyakarta : Ekonisia.

Muhamad. 2014. Manajemen Keuangan Syari'ah (Analisis Figh \& Kevangan). Edisi Pertama. Yogyakarta : UPP STIM YKPN.

Nurmala. 2006. Pengaruh Kebijakan Dividen terhadap Harga Saham Perusahaan-perusahaan

Otomotif di Bursa Efek Jakarta. Jurnal Manajemen dan Akuntansi $9: \mathrm{h}: 17-24$

Otoritas Jasa Keuangan. 2015. Laporan Perkembangan Keuangan Syariah 
Adityasari, et al/ Jurnal Ekonomi Syariah Teori dan Terapan Vol. 5 No. 5 Mei 2018: 420-432; DEterMINAN

KEBIJAKAN DIVIDEN PADA PERUSAHAAN MANUFAKTUR DI JAKARTA ISLAMIC INDEX

(http://www.ojk.go.id) diakses 10 Februari 2017).

Riyanto, Bambang. 2001. Dasar-dasar Pembelanjaan Perusahaan. Edisi keempat. Yogyakarta: BPFE

Ryandono, Muhammad Nafik H. 2009. Bursa Efek dan Investasi Syariah. Jakarta: Serambi.

Sartono, Agus. 2001. Manajemen Kevangan Teori dan Aplikasi. Yogyakarta: BPFE.

Sarwoko, 2005. Dasar-dasar Ekonometri. Penerbit Andi, Yogyakarta

Shihab, Quraish. 2009. Tafsir Al-Mishbah : Pesan, Kesan dan Keserasian AlQur'an. Jakarta : Lentera Hati.

Sudarsi, Sri. 2002. "Analisis Faktor-Faktor Yang Mempengaruhi Devident Payout Ratio pada Industri Perbankan yang Listed Di Bursa Efek Jakarta (BEJ)". Jurnal Bisnis dan Ekonomi. Vol.9, No.1, Maret. Hal. 76-88.

Sutedi, Adrian. 2011. Pasar Modal Syariah (Sarana Investasi Keuangan Berdasarkan Prinsip Syariah). Jakarta : Penerbit Sinar Grafika

Suwaldiman dan Ahmad Aziz. 2006. "Pengaruh Insider Ownership dan Risiko Pasar terhadap Kebijakan Dividen. Kajian Bisnis dan Manajemen. Vol.8 No.1, Januari 2006. Hal 53-64

Tandelilin, Eduardus. 2010. Portofolio dan Investasi Teori dan Aplikasi. Edisi Pertama. Yogyakarta : Kanisius

Widarjono, Agus (2007). Ekonometrika Teori dan Aplikasi . Yogyakarta: Ekonisia FE UII

Regulasi

Peraturan Bapepam-LK Nomor II.K.1

Peraturan OJK POJK No.17/POJK.04/2015

Internet

http://www.astra.co.id/

www.idx.co.id

http://www.indocement.co.id/

http://www.kalbe.co.id/

http://www.semenindonesia.com/

https://www.unilever.co.id/ www.ojk.go.id

http://finance.yahoo.com

www.ekbis.sindonews.com 